\title{
Article
}

\section{Stand up for recalcitrance!}

\author{
Mckeown, Michael
}

Available at http://clok.uclan.ac.uk/14929/

Mckeown, Michael ORCID: 0000-0003-0235-1923 (2016) Stand up for recalcitrance! International Journal of Mental Health Nursing, 25 (6). pp. 481483. ISSN 1447-0349

It is advisable to refer to the publisher's version if you intend to cite from the work. http://dx.doi.org/10.1111/inm.12239

For more information about UCLan's research in this area go to http://www.uclan.ac.uk/researchgroups/ and search for < name of research Group>.

For information about Research generally at UCLan please go to http://www.uclan.ac.uk/research/

All outputs in CLoK are protected by Intellectual Property Rights law, including Copyright law. Copyright, IPR and Moral Rights for the works on this site are retained by the individual authors and/or other copyright owners. Terms and conditions for use of this material are defined in the policies page.

\section{CLoK}

Central Lancashire online Knowledge www.clok.uclan.ac.uk

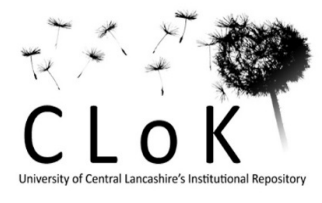




\title{
Stand up for recalcitrance!
}

\author{
Mick McKeown
}

Accepted for publication: International Journal of Mental Health Nursing

This is an urgent plea for action. Action for progressive change: in services and societies that frame them. Concerted action to protest and resist hurtful orthodoxies and, more importantly, communicative action to conceive alternative, better futures and seek the change that will get us there. Some of this action is already underway. Some of it barely escapes the bounds of imagination. Too little of it involves mental health nurses, and, arguably, this must be remedied. Hence this plea. I wish to make a case for a new professional identity that embraces resistance and action for change, seeking democratised solutions for service level and societal deficiencies. Recalcitrant professionalism can seek constructive alliances with recalcitrant consumers, service users and survivors to resist and transform the forces of oppression that assail us all.

\section{Indignation and recalcitrance}

Those of us who work within mental health services, are otherwise concerned with the welfare of our fellow citizens, or who simply wish for a better world are, right now, in the midst of a pivotal moment in history. Caught up in a perfect storm of inequality, austerity and a triumphant neoliberalism, wider welfare and mental health services face stark choices over sustainability or survival. Successive iterations of misguided funding cuts afflict communities to the point where depression aptly describes distressed economies and individuals alike

The intertwined doctrines of neoliberalism and psychiatry dominate society and mental health care respectively, yet both are subject to plausible moral and evidential critique. Mental health nursing faces a number of quite profound crises of legitimacy (McKeown \& White 2015) as does the global political-economy within which our work is shaped and organised (Crouch 2011). We urgently need to address these matters. Some of them are of our own making; much else subject to powerful, systemic forces. What is clear is that passivity in the face of these challenges is ill-advised. Posterity will judge whether we acted with the appropriate amount of courage, compassion and intelligent criticality to address the profound challenges that prompt this entreaty. 
Austerity and unfairness begets anger and indignation, in turn these emotions can provoke rebellious resistance and recalcitrance. Faced with psychiatry as the only show in town, any person who resists diagnostic labelling and medication, especially more coercive forms, is compelled to take on the identity of recalcitrant. Breeze and Repper (1998: 1308) pointed out a tendency amongst nurses to identify individuals who challenge nursing competence and control as 'difficult' patients; reluctant to accept the 'legitimate power of the professionals'. In this context, recalcitrance is both a pejorative applied by staff, or can be positively claimed by patients themselves as they rebel against diagnoses, treatments and compulsion or the entire psychiatric episteme. For some individuals subject to psychiatric coercion, the struggle erupts in violence and quite literally fighting against institutional regimes and the staff who service them.

The terminology of recalcitrance also appears in critical analyses of social movement activism deployed against global capitalism and other oppressions (Clarke 2007, Law \& Mooney 2006). Forms of psychiatric survivor activism, such as those accounted for within the emergent field of Mad Studies, are arguably associated with such a recalcitrant activist identity (see Le Francois et al. 2014, Burstow et al. 2015); positioned contra both biopsychiatry and neoliberalism, at the confluence of class and identity politics (Thomas in press). Taking a recalcitrant position involves, as much as anything, an intuitive or critically aware struggle over legitimacy. Either way, the sense of injustice that drives recalcitrance can be profound and is felt viscerally.

\section{Psychopolitics}

John Hopton (1997) ruthlessly exposed mental health nursing's capacity for self-delusion in attempting to define itself as a force for progressive, humanist good in the absence of a more critical disposition towards dominant bio-psychiatry. Hence, we must caution ourselves to both ensure changes to practice are sufficiently deep, enduring and authentic and predicated upon lessons gleaned from honest appreciation of available critique. All else will remain illegitimate and merely serve to continue the crisis. Hopton draws upon previous radical critics of the mental health system. Notable within this lineage, but missing from Hopton's treatise, is Peter Sedgwick, whose seminal work, Psycho Politics, has, after a 33 year gap, been republished for a modern readership. 
Sedgwick $(2015,1982)$ was a labour movement activist, psychologist, carer and user of services whose contribution is important for its constructive vision for mental health care and tragic in that he took his own life soon after publication of his most famous work. Sedgwick's genius was to combine socialism with a call for a more sophisticated politics of mental health. His view of an alternative future is implicitly psycho-social, democratic and tied to an explicitly radical political analysis combining elements of Marxism and anarchism: a critique of an unfair society that on an endemic scale precipitates mental distress and a prevailing psychiatric system that fails adequately to understand and treat it. For Sedgwick, however, stopping at the critique without offering viable, wholesale alternatives is an absurd nihilism, and can be put to service by unscrupulous governments concerned with dismantling the state and provision of health and welfare services (a defining feature of neo-liberalism). For these reasons he was dismissive of celebrated anti-psychiatrists.

Sedgwick's clarion call is for more and better services. Arguing for this, he contemplates how a politics of prefiguration, built on alliances of workers, service users, refusers, and families, can create more democratised forms of care provision. The end objective of better, democratically organised care, and the prefigurative means by which this ideal state might be realised are thus an antidote to the ways in which present approaches alienate patients and staff. Prefigurative politics opens up spaces capable of holding the turbulence of indignation, harnessing recalcitrance towards positive, creative thinking, communication and action.

\section{Cross-sectional alliances}

Both service user social movements and health worker trade unions provide an outlet for recalcitrance. The human geographer Simon Springer $(2012,2016)$ has written various provocative calls to arms for recalcitrants, which present prefigurative politics as a basis for social transformations. These are grounded in anarchist ideas, citing, like Sedgwick, founding figures such as Kropotkin. The potential to think imaginatively about social change, movement politics and activism, and how this may translate productively into mental health care environs is energising and exciting in equal measure. Hannah Proctor's (2016) reading of Sedgwick's affinity for prefiguration points to the potential for creating radical, democratised and relational alternative forms of therapy. 
Such a turn could lead us to consider more situated, dialogic, democratic, forms of care that are not so bound to coercion and medication. We already have examples such as therapeutic communities or the newer Open Dialogue to guide us. An ideal but not yet realised form might move beyond therapeutic relations to include the democratic voices of both service users and workforce in decision making about how services are organised and resources allocated (McKeown et al. 2013). If this seems far-fetched for those of us used to inflexible, hierarchical governance systems we might ask why do citizens expect democracy within civil society (albeit in the limited form of regular elections) and not in other public spheres, such as workplaces or clinics?

How do we make this happen? What action should mental health nurses take? One obvious possibility is to become more active within the organisations for social change close to hand, our representative unions. But these have their own problems of legitimacy and urgent need for renewal. So merely joining unions is insufficient. We need to reinvent them as recalcitrant and democratic forces, seeking the democratisation of our workplaces and alliances with recalcitrants beyond the workplace:

the struggle ... requires a new, imaginative - indeed utopian - counter-offensive: a persuasive vision of a different and better society and economy ... to help construct a new type of politics (Hyman 2016: 22).

Contact your unions and local groups of mental health activists; have conversations; express your views; be open to persuasion. Concomitantly, therapeutic process can be democratised in the invention of a new professionalism that seeks more equal, less oppressive relations with persons in mental distress. This has to be organised collectively, and part of any change will be active communication, or indeed protest, amongst colleagues, activists and service users. Starting points for this dialogue are already with us, to be found in places such as the blogging and social media of The Critical Mental Health Nurses Network, Mad Studies and Recovery in the Bin, or the pages of Asylum: the magazine for democratic psychiatry, now in its $30^{\text {th }}$ year. In clinical practice, we need to embrace alternatives to bio-medicine and coercion, seeking, cooperatively with service users, to deploy our nursing skills to shape new forms of democratised care better suited to the $21^{\text {st }}$ century. In the short term, we must consider how we react to recalcitrant patients; even in circumstances of aggression we need 
to reach for understanding and not rush to restrain and medicate. The least we can do is adopt a prefigurative stance and treat each other as we want the world to actually be.

\section{Conclusion}

The work good mental health nurses do, or attempt to do, is entirely commensurable with the values and skills necessary for a more relational and democratised model of care. At every turn, however, this is undermined by budget cuts on top of historically disproportionate under-funding compared to general services. We are also challenged over unfairness and injustice by the very service users and families we would seek alliances with. Alternate, democratised forms of support offer one means of negotiating a way out of these profound crises of care and legitimacy. So, mental health nurses and their trade unions cannot stop at defending current service configurations from the attrition of austerity cuts and privatisation. Instead, we need to construct a vision for compassionate, cooperative, and humane alternative futures. Within our ranks and those of our putative allies we have the imagination, creativity and skills for this task. It is time for mental health nurses to understand and empathise with recalcitrant patients and assume a more recalcitrant identity for ourselves. Let's stand up for recalcitrance, and do it soon!

\section{References}

Breeze, J. \& Repper, J. (1998). Struggling for control: the care experiences of 'difficult' patients in mental health services. Journal of Advanced Nursing, 28, 1301-1311.

Burstow, B., LeFrancois, B. \& Diamond, S. (eds) Psychiatry disrupted: theorizing resistance and crafting the revolution. Montreal, QC: McGill/Queen's University Press.

Clarke, J. (2007) Citizen-consumers and public service reform: At the limits of neoliberalism? Policy Futures in Education, 5, 239-248.

Crouch, C. (2011). The Strange Non-Death of Neoliberalism. Maladen, MA: Polity Press. Hopton, J. (1997). Towards a critical theory of mental health nursing. Journal of Advanced Nursing, 25, 492-500.

Hyman, R. (2016) The very idea of democracy at work. Transfer, 22, 1, 11-24.

Law, A. \& Mooney, G. (2006) The maladies of social capital II: resisting neo-liberal reformism'. Critique, 34, 253-268. 
LeFrancois, B., Menzies, R. \& Reaume, G. (eds) Mad matters: a critical reader in Canadian mad studies. Canadian Scholars Press, Toronto. International Journal of Mental Health Nursing, 22, 472.

McKeown, M., Jones, F. \& Spandler, H. (2013) Challenging austerity policies: democratic alliances between survivor groups and trade unions. Mental Health Nursing, 33, 6, 26-29.

McKeown, M. \& White, J. (2015) The future of mental health nursing: are we barking up the wrong tree? Journal of Psychiatric and Mental Health Nursing, 22, 724-730.

Proctor, H. (2016) Lost minds: Sedgwick, Laing and the politics of mental illness. Radical Philosophy, 197, 36-48.

Sedgwick, P. (2015, 1982) Psychopolitics. London, Unkant.

Springer, S. (2012) Anarchism! What geography still ought to be. Antipode, 44, 1605-1624.

Springer, S. (2016) Fuck neoliberalism. researchgate.net

Thomas, P. (in press) Psycho politics, neoliberal governmentality and austerity. Self \& Society, 